\title{
Heberferon May Contain The SARS-Cov-2 Infection
}

\author{
Iraldo Bello Rivero ${ }^{1 *}$, Yaquelin Duncan-Roberts ${ }^{1}$ and Dania Vazquez-Blomquist ${ }^{2}$ \\ ${ }^{1}$ Department of Clinical Investigations, Center for Genetic Engineering and Biotechnology, Cuba \\ ${ }^{2}$ Department of Genomic, Center for Genetic Engineering and Biotechnology, Cuba
}

*Corresponding author: Iraldo Bello Rivero, Department of Clinical Investigations, Center for Genetic Engineering and

Biotechnology, Cuba

\begin{tabular}{|c|c|}
\hline ARTICLE INFO & ABSTRACT \\
\hline Received: 慧 September 08, 2020 & Citation: Iraldo Bello Rivero, Yaquelin Duncan-Roberts, Dania Vazquez-Blomquist. \\
\hline Published: & $\begin{array}{l}\text { Heberferon May Contain The SARS-Cov-2 Infection. Biomed J Sci \& Tech Res 30(4)-2020. } \\
\text { BJSTR. MS.ID.004974. }\end{array}$ \\
\hline
\end{tabular}

\section{Introduction}

Human coronavirus is an important agent causing mild-tosevere respiratory tract infections in humans. It is clear that viral dissemination is determinant in the establishment of severe COVID-19[1]. Therefore, the shortening of time to virus clearance will impact very favorable in the disease outcome in COVID-19 infected patients.Due to its direct (2-5 OAS, PKR) and indirect (immune mediated) antiviral properties, interferons (IFNs) have been used for the treatment of viral infections[2]. Insufficient activation of IFN system is refereed as principal cause of innate immune failure to control viral persistence. $\mathrm{T}$ cell-mediated adaptive immune response is a fundamental factor for clearing and maintaining long-term suppression of viral infections[3]. We designed and conducted an open-label randomized and controlled clinical trial that assessed the efficacy and safety of the combination of IFNs alpha-2b and gamma (HeberFERON) versus IFN- $\alpha 2$ bpatients with COVID-19.

HeberFERON significantly cleared the virus after four days of treatment when compared with Heberon Alpha R (IFN-alpha2b) alone. Heberon Alpha R alone also showed efficacy in the viral elimination. Both formulations of IFNs were safe and positively impacted on the resolution of the disease symptoms. None of the patients developed severe COVID-19[4]. In the ESPERANZA trial in asymptomatic patients, a lower rate of viral elimination was observed for both IFNs. However, the HeberFERON group showed a $70.6 \%$ of elimination in comparison to $46.7 \%$ for control group[5]. It was suggested that administration of antiviral medications at the beginning of the infection (within 7-10 days of starting the symptoms) might improve outcome of patients with COVID-19[6]. Additionally, early treatment with IFNs was recommended in treatment of MERS[7]. An early application of antiviral therapy accelerating viral clearance can delay pro-inflammatory cell development, activation and their infiltration that will favor a higher survival rate.

Following the Cuban Protocol for Management of COVID-19[8]. we were able to recruit patients during a window of 7-10 days from symptoms onset which is a good time to start to contribute with the innate and adaptive immune response with the use of the combination of IFN- $\alpha 2 \mathrm{~b}$ and gamma, where the IFN-gamma plays a key role in linking the innate and adaptive immune response[9]. Although most countries do not pay adequate attention to asymptomatic people, this population of infected patients negatively impacts the global outcomes of the disease; therefore the treatment and follow-up of these patients are important to control the pandemic. The use of IFNs may be a determinant factor in the control of the disease in both symptomatic and asymptomatic patients, as reflected in this trial, where HeberFERON is most effective in the elimination of viral replication in both symptomatic and asymptomatic patients. The use of HeberFERON could be a distinctive element in this preventive and therapeutic strategy.

\section{References}

1. Vardhana SA and Wolchok JD (2020) The many faces of the anti-COVID immune response J. Exp Med 217(6): e20200678.

2. Channappanavar R, Fehr AR, Vijay R, Matthias Mack, Jincun Zhao, et al. (2016) Dysregulated Type I Interferon and Inflammatory Monocyte- 
Macrophage Responses Cause Lethal Pneumonia in SARS-CoV-Infected Mice. Cell Host Microbe19(2): 181-193.

3. Ahmed R, Salmi A, Butler LD, M B Oldstone (1984) Selection of genetic variants of lymphocytic choriomeningitis virus in spleens of persistently infected mice. Role in suppression of cytotoxic T lymphocyte response and viral persistence. J Exp Med 160: 521-540.

4. Idelsis Esquivel-Moynelo I, Pérez-Escribano J, Duncan-Roberts Y, Vazque-Blomquist D, Bequet-Romero $\mathrm{M}$, et al. Effect and safety of combination of interferon alpha- $2 b$ and gamma or interferon alpha$2 \mathrm{~b}$ for negativization of SARS-CoV-2 viral RNA. Preliminary results of $\mathrm{a}$ randomized controlled clinical trial. medRxiv preprint.

5. Binh T Ngo, Paul Marik, Pierre Kory, Leland Shapiro, Raphael Thomadsen, et al. (2020) systematic analysis of the time course to develop therapeutic interventions for COVID-19. medRxiv preprint.

ISSN: 2574-1241

DOI:10.26717/BJSTR.2020.30.004974

Iraldo Bello Rivero. Biomed J Sci \& Tech Res

(C) This work is licensed under Creative

Submission Link: https://biomedres.us/submit-manuscript.php
6. Wang Y, Zhang D, Du G, Ronghui Du, Jianping Zhao, et al. (2020) Remdesivir in adults with severe COVID-19: a randomised, double-blind, placebocontrolled, multicentre trial. Lancet (20): 31022-31029.

7. Channappanavar R, Fehr AR, Zheng J, Christine Wohlford-Lenane, Juan E Abrahante, et al. (2019) IFN-I response timing relative to virus replication determines MERS coronavirus infection outcomes. J Clin Invest 130(9): 3625-3639.

8. Protocolo De Actuación Nacional Para La COVID-19. Versión 1.4.

9. Tang F, Liu W, Zhang F, Zhong-Tao Xin, Mao-Ti Wei, et al. (2008) IL-12 RB1 genetic variants contribute to human susceptibility to severe acute respiratory syndrome infection among Chinese. PLoS One 3(5): e2183.

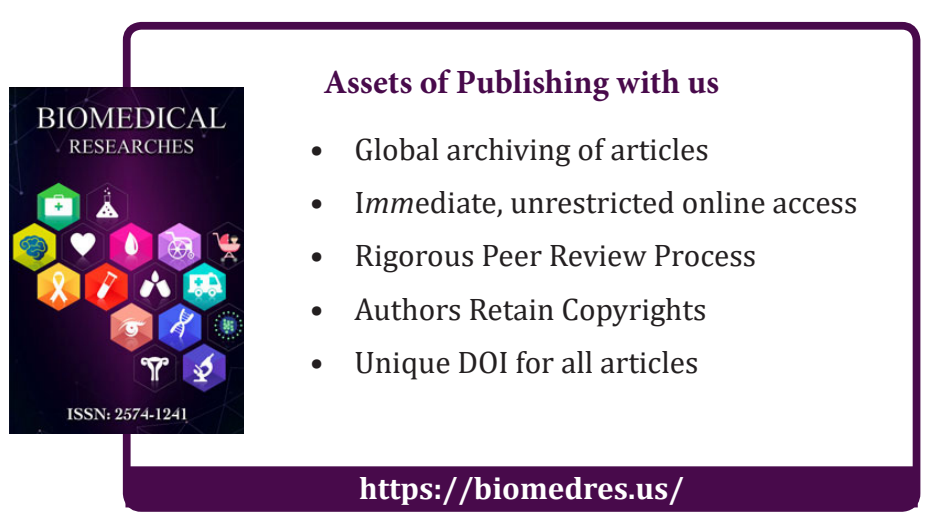

